Kaja Wójcik

ORCID: 0000-0002-1132-521X

Uniwersytet Wrocławski

https://doi.org/10.19195/1733-5779.38.24

\title{
Redefinicja postrzegania ciała w dyskursie medialnym - ciałopozytywność i ciałoneutralność
}

Słowa kluczowe: ciałopozytywność, ciałoneutralność, fat activism, dyskurs medialny, wizerunek ciała

Keywords: body positivity, body neutrality, fat activism, media discourse, body image

Abstrakt: Ciałopozytywność i ciałoneutralność to zjawiska o charakterze społecznym, których manifestacje od kilku lat dostrzegalne są w przestrzeni medialnej. Stojące za owymi pojęciami sposoby rozumienia ciała i cielesności trafiają na nieposiadający długiej historii ruchu fat activism polski grunt, zyskując na popularności widocznej $\mathrm{w}$ najpopularniejszych mediach społecznościowych. Poniższy artykuł stanowi próbę nakreślenia definicji i genezy ruchów fat activism, ciałopozytywności i ciałoneutralności, a jednocześnie jest pretekstem do krytycznego namysłu nad polskim tłumaczeniem tych terminów i przeglądem (jednostkowych) polskojęzycznych publikacji odnoszących się do nowo powstałych ruchów.

\section{Redefining the perception of the body in media discourse - body positivity and body neutrality}

\footnotetext{
Abstract: Body positivity and body neutrality are social phenomena manifestations which have been visible in the media discourse for several years. In Polish social media, body positivity and body neutrality gained significant popularity, despite the short history of fat activism. The present article attempts to outline the elements of definition and origin of fat activism, body positivity, and body neutrality, at the same time being a pretext for reflection on the Polish translation and a review of individual Polish publications.
}

Ciałopozytywność i ciałoneutralność to zjawiska o charakterze społecznym, których manifestacje od kilku lat dostrzegalne są w przestrzeni medialnej. Choć pojęcia te, a tym samym stojące za nimi interpretacje cielesności, wywodzą się ze środowisk aktywistycznych w Stanach Zjednoczonych, wydaje się, że z coraz większym powodzeniem funkcjonują również w polskiej rzeczywistości społecz- 
nej i w coraz większym stopniu reprezentują normy i wartości młodego pokolenia. Niniejsza praca przeglądowa stanowi próbę nakreślenia genezy i definicji tych zjawisk, które mają na celu promocję redefinicji cielesności i społecznego sposobu postrzegania ciała. Historia ruchów działających w tej sprawie, a powstałych stosunkowo niedawno, nie została jeszcze obszernie opisana w źródłach naukowych, zwłaszcza tych polskojęzycznych. $Z$ tego powodu przywoływane w niniejszym artykule fakty historyczne są zaczerpnięte również z literatury popularnonaukowej i formatów dziennikarskich. Warto nadmienić, że ze względu na dosyć krótką historię opisywanych tu zjawisk znaczna część aktywistów i aktywistek, założycieli i założycielek ruchów oraz osób będących świadkami wydarzeń jest medialnie aktywna. Powołuję się więc także na wywiady, treści publikowane w mediach społecznościowych tych osób oraz wpisy na stronach internetowych organizacji związanych z ruchem.

W Polsce tematyką związaną z wizerunkiem własnego ciała zajmują się głównie badacze i badaczki reprezentujący nurt psychologiczny. Z kolei kwestiami ciałopozytywności i ciałoneutralności z perspektywy nauk o komunikacji zajmowali się kolejno:

- Dorota Dąbrowska, która w artykule Filmowe przedstawienia otyłości - od krytyki do emancypacji ${ }^{1}$ podejmuje tematykę ciał nieznormalizowanych z perspektywy zaangażowanego społecznie filmu fabularnego i dokumentalnego;

—Żaneta Wańczyk, która w swojej pracy magisterskiej zatytułowanej Oddziatywanie aplikacji Instagram na identyfikacje, emocje i relacje młodych dorostych ${ }^{2}$ wprowadza pojęcie ciałopozytywności, gdy opisuje studium przypadku profilu @ kayaszu ${ }^{3} \mathrm{w}$ portalu Instagram, prowadzonego przez wieloletnią działaczkę aktywistyczną Kayę Szulczewską. Autorka tekstu stwierdza: „Aktywistka udowadnia na swoich platformach, jak łatwo można manipulować obrazem w mediach społecznościowych, demaskuje kłamstwa »fit świata« i obsesję na piękno"4;

— Adrian Mróz opisujący w artykule Inność a Tożsamość: Estetyka mężczyzn w obliczu toksycznej męskości $i^{5}$ podjętą w ramach projektu „The EveryMan Project” próbę re-formacji estetyki mężczyzn. Artysta Tarik Caroll podjął się stwo-

${ }^{1}$ D. Dąbrowska, Filmowe przedstawienie otyłości - od krytyki do emancypacji, „Annales Universitatis Paedagogicae Cracoviensis. Studia de Cultura" 12, 2020, nr 4.

2 Ż. Wańczyk, Oddziaływanie aplikacji Instagram na identyfikację, emocje i relacje młodych dorostych, praca magisterska, 2020, https://www.academia.edu/44461320/Oddzia\%C5\%82ywanie aplikacji_Instagram_na_identyfikacj $\% \mathrm{C} 4 \% 99$ _emocje_i_relacje_m $\% \mathrm{C} 5 \% 82$ odych_doros $\% \mathrm{C} 5 \%$ 82ych_Praca_magisterska (dostęp: 13.04.2021).

3 K. Szulczewska,@kayashu, https://www.instagram.com/kayaszu/?hl=pl (dostęp: 14.04.2021).

4 Ż. Wańczyk, op. cit., s. 24.

5 A. Mróz, Inność a Tożsamość: Estetyka mężczyzn w obliczu toksycznej męskości, „Kultura i Historia" 35, 2019, nr 1. 
rzenia ciałopozytywnych sesji zdjęciowych, gdzie zrywa ze stereotypowym wizerunkiem mężczyzn, a modele ,przedstawieni są jako bliscy sobie, przytuleni, wrażliwi, odsłonięci i bezbronni" 6 .

Wspomniane prace, choć niewątpliwie wpisują się w naukowe rozważania dotyczące opisywanych tu zjawisk, nie traktują pojęć ciałopozytywności i ciałoneutralności w sposób kompleksowy czy przeglądowy, a raczej analizują konkretne przypadki i przykłady działań aktywistycznych.

\section{Definicje i znaczenia}

Przy podejmowaniu próby rekonstrukcji znaczeniowej analizowanych pojęć pierwsze wyzwanie bez wątpienia stanowi kwestia polskiego tłumaczenia. Termin body positivity (ang.) zdaje się nie stwarzać większych problemów. Polskie tłumaczenie, jak i definicję hasła, odnaleźć można zarówno w ogólnodostępnych słownikach internetowych, jak i na stronie internetowej Obserwatorium Językowego Uniwersytetu Warszawskiego (OJUW) ${ }^{7}$, gdzie zarejestrowane zostało w 2018 roku. Ciałopozytywność w internetowym Słowniku języka polskiego ${ }^{8}$ definiowana jest jako ,akceptacja własnego ciała”", na stronie zaś OJUW zostaje opisana następująco:

ciałopozytywność: „akceptowanie swojego ciała bez względu na wygląd”.

Mam nadzieję, że jako społeczeństwo nauczymy się dostrzegać piękno w różnorodności, bo tylko to gwarantuje według mnie indywidualną ciałopozytywność, w której liczy się i ciało, i umysł (vogue.pl).

Żyjemy w kulturze, w której uważa się, że absolutnie wszystkie ciała wymagają jakichś napraw — do tego stopnia, że przeprowadzenie normalnej dyskusji na temat ciałopozytywności $\mathrm{z}$,ludźmi z internetu” wydaje się zwyczajnie niemożliwe (proseksualna.pl) ${ }^{10}$.

Warto zaznaczyć, że powyższe stwierdzenia nie tworzą kompleksowej definicji pojęcia i zdaje się, że nie są rozpowszechnione, gdyż powstały prawdopodobnie po 2010 roku $^{11}$. Ruch ciałoneutralności pozwolił na wyróżnienie wielu kolejnych interpretacji pojęć. Tę różnorodność można zauważyć w polskich mediach:

Body neutrality to idea, w myśl której kwestia ciała przestaje być istotna. Nie chodzi w niej o to, by, tak jak w ciałopozytywności, pokochać swoje kształty i czuć się z nimi dobrze. Zwolenniczki

${ }^{6}$ Ibidem, s. 84.

7 https://nowewyrazy.uw.edu.pl.

8 www.sjp.pl.

9 Ciałopozytywność, https://sjp.pl/cia\%C5\%82opozytywno\%C5\%9B\%C4\%87 (dostęp: 20.04.2021).

10 T. Dec, Ciałopozytywność, Obserwatorium Językowe Uniwersytetu Warszawskiego. Najnowsze Słownictwo Polskie, https://nowewyrazy.pl/haslo/cialopozytywnosc.html (dostęp: 14.05.2021).

${ }^{11} \mathrm{O}$ problemach z określeniem genezy ruchu piszę w dalszej części artykułu. 
nowego ruchu uważają, że powinniśmy skupić się na swoich cechach i osiągnięciach, a nie na wyglądzie ${ }^{12}$.

Body positivity opowiada się za akceptacją wszystkich ciał — bez względu na ich formę, rozmiar, wygląd. Stara się też zmienić społeczne nastawienie do takich obszarów, jak dieta, aktywność fizyczna, zabiegi medycyny estetycznej. [...] Jeśli też masz wrażenie, że ciałopozytywność jest zbyt restrykcyjnym ruchem, zajrzyj na Instagram jameelajamilofficial — to znakomite źródło inspiracji dla wszystkich, którzy zdecydowanie lepiej czują się z neutralnym stosunkiem do swojego wyglądu ${ }^{13}$.

Ciałopozytywność nazwałabym ruchem, który jest kretem kopiącym dół dla ciało neutralności [!]. Nie da się przejść z obsesji piękna do ciało neutralności [!] bez przejścia przez ciałopozytywność. [...] Natomiast ciałoneutralność to ruch, który idzie o krok dalej. Bardzo szanuję moje ciało, bo mogę dzięki niemu funkcjonować. Natomiast jest to współpraca i odchodzę od tego, żeby się na nim skupiać, tak jak w ciałopozytywności ${ }^{14}$.

W wypadku dwóch pierwszych cytatów ciałopozytywność i ciałoneutralność interpretować można jako silnie opozycyjne postawy. Jeżeli ta pierwsza ma na celu zrezygnowanie z pracy nad swoim ciałem na rzecz pracy nad umysłem a tym samym próbę zmiany osobistych przekonań, by zaakceptować siebie - to znaczy, że można uznać ją za opresyjną. W tej sytuacji ciałoneutralność niweluje ową opresję, dając przyzwolenie na niemyślenie o swoim ciele i nieskupianie się na jego wyglądzie. W ramach innego rozumienia zakłada się procesualny charakter postaw. W tym przypadku ciałopozytywność i ciałoneutralność nie wykluczają się, gdyż reprezentują różne stany emocjonalne. Akceptacja wyglądu pozwala jednostce na stopniowe dystansowanie się względem swojego ciała, pewnego rodzaju zapominanie o nim, a tym samym osiągnięcie stanu, w którym przestaje ono stanowić centrum uwagi.

Kolejnym wyzwaniem translatorskim jest tłumaczenie nazwy ruchu, który zapoczątkował rewolucyjne myślenie o cielesności - fat activism. W internetowej wersji słownika polsko-angielskiego wydawnictwa PONS słowo fat tłumaczone jest zarówno jako rzeczownik 'tłuszcz', czasownik 'tyć' oraz przymiotniki 'gruby', 'pokaźny', 'tłusty'15. W konsekwencji rzeczownik fat activist można jednocześnie tłumaczyć jako 'aktywist(k)a w sprawie tłuszczu', jak i 'gruby aktywista / gruba aktywistka'. Tłumaczenia te niosą ze sobą skrajnie różny bagaż znaczeniowy, z tego względu w niniejszym tekście zdecydowałam się zachować anglojęzyczną

12 K. Seiler, Już nie body positiv, tylko body neutrality. Nowy feministyczny ruch walczy z kultem ciała, https://www.wysokieobcasy.pl/wysokie-obcasy/7,80530,25423882,juz-nie-body-positive-tylko-body-neutrality-nowy-feministyczny.html?disableRedirects=true (dostęp: 14.05.2021).

${ }^{13}$ Ciałopozytywność - czy rzeczywiście zawsze tak pozytywna jak nam się wydaje, https:// www.tamaragonzalezperea.com/2020/11/cialopozytywnosc-czy-rzeczywiscie-zawsze-tak-pozytywna-jak-nam-sie-wydaje.html (dostęp: 14.05.2021).

14 A. Woźniak, Pomęczę ciało, żeby ulżyć duszy. Jak nauczyć się akceptować siebie i swoja cielesność, https://www.wysokieobcasy.pl/Instytut/7,163393,26426309,pomecze-cialo-zeby-ulzyc-duszy-jak-nauczyc-sie-sie-akceptowac.html (dostęp: 14.05.2021).

15 https://pl.pons.com/t\%C5\%82umaczenie/angielski-polski/fat (dostęp: 14.05.2021). 
formę, która trafniej określa przyjęte rozumienie tego pojęcia jako związanego z tłuszczem oraz oswajaniem i normalizowaniem widoku ciała pokrytego jego warstwą.

\section{Fat activism}

Genezy ciałopozytywności nie sposób opisać w oderwaniu od już wspomnianego - i poprzedzającego powstanie tego zjawiska — ruchu fat activism. Charlotte Cooper — brytyjska aktywistka, terapeutka i socjolożka z uniwersytetu w Limerick — opisuje powstanie ruchu i jego założenia. Autorka tłumaczy fat activism jako alternatywny dyskurs na temat otyłości powstały w kontrze do stereotypowego wizerunku osób otyłych (kojarzonych z chorobą, lenistwem, chciwością, żałością, brakiem wartości — konstruowanych społecznie jako jednostki, które należy leczyć i których „,powstawaniu” należy zapobiegać) ${ }^{16}$. MaryAnn Kozlowski opisuje fatness (ang. grubość/otyłość/otłuszczenie/tłuszcz) jako konstrukt społeczny, medyczny i polityczny opierający się na zbieżności specyficznych dla danego okresu: dyskursu medycznego, dominujących ideologii oraz wyobrażeń o rasie, klasie i płci ${ }^{17}$.

Cooper, definiując aktywizm jako ,celowe działania zmierzające do zmiany”18, wskazuje na mnogość celów, założeń, priorytetów i praktyk istotnych dla ruchu. Jednocześnie uznaje, że obecnie ,,cele aktywistów funkcjonują w obszarach dyskursu o równości, prawach (człowieka), widoczności i uznaniu, akceptacji i samorealizacji osobowości [przeł. — K.W.]"19. W artykule What's Fat Activism? ${ }^{20}$ charakteryzuje trzy fale fat activism $i$ umiejscawia je kolejno na osi czasu: pierwsza fala obejmuje lata 1967-1989, druga — lata dziewięćdziesiąte XX wieku, trzecia - rozpoczyna się od 2000 roku.

Ruch zapoczątkowany został w USA, gdzie w czerwcu 1967 roku doszło do pierwszej interwencji aktywistycznej na terenie nowojorskiego Central Parku. Uczestnicy biorący udział w proteście skandowali hasła: „Fat power” czy „Buddha was fat" ${ }^{21}$. Protestujący, w celu unaocznienia problemu niechęci do osób grubych, palili książki o tematyce dietetycznej i zdjęcia popularnej w tamtym czasie

16 Ch. Cooper, What's Fat Activism?, https://ulir.ul.ie/bitstream/handle/10344/3628/Cooper_2008_fat.pdf (dostęp: 10.02.2021).

${ }_{17} \mathrm{M}$. Kozlowski, I feel so fat: The meanings and uses of „Fat” as an Identifier, „A Journal of Woman Studies" 40, 2019, nr 3, s. 187.

18 Ch. Cooper, What's Fat...

19 „Fat activist objectives are centred on discourses of equality, rights, visibility and recognition, acceptance and self-actualising personhood", Ch. Cooper, Fat Activism: A Queer Autoethnography, s. 15, https://core.ac.uk/download/pdf/59349191.pdf (dostęp: 10.02.2021).

${ }^{20}$ Ch. Cooper, What's Fat...

21 Ibidem. 
brytyjskiej modelki Twiggy, a także spożywali wspólne posiłki ${ }^{22}$. Działania te były szeroko komentowane w mediach, między innymi w magazynie „The New York Times", w którym 5 czerwca 1967 roku opublikowano artykuł Curves Have Their Day in Park; 500 at a 'Fat-in' Call for Obesity ${ }^{23}$. Ruch stawał się coraz bardziej popularny i tak w kolejnych latach powstały organizacje: NAAFA (National Association to Advance Fat Acceptance) $)^{24}$ zajmująca się ochroną praw osób grubych (fat-rights) ${ }^{25}$ oraz Fat Underground. Ta ostatnia była kolektywem stworzonym przez feministyczną grupę kobiet (fat-feminists), której przedstawicielki Judy Freespirit i Aldebaran w listopadzie 1973 roku opublikowały Fat Liberation Manifesto $^{26}$. Jego treść odnosiła się do pozycji społecznej osób grubych — dyskryminowanych i wykluczanych w taki sam sposób, jak wyklucza się ze względu na klasizm, rasizm, seksizm, ageizm, kapitalizm i imperalizm ${ }^{27}$. Kolejnym przełomem było wydanie przez brytyjską psychoterapeutkę Susie Orbach w 1978 roku pierwszego antydietetycznego przewodnika Fat Is a Feminist Issue 28 „popularyzującego ideę, że dieta i nienawiść do ciała są uciskające, a dysmorfia ciała i zaburzenia odżywiania są zakorzenione w mizoginii" 29 . W latach dziewięćdziesiątych chęć poszerzania rynków przez marki odzieżowe i modowe sprawiła, że dostrzeżono lukę sprzedażową. Zaczęły powstawać działy „plus-size” w sklepach sieci H\&M czy Etam ${ }^{30}$. Kolejne lata przyniosły wciąż zwiększającą się reprezentację osób grubych w mediach, która sprzyjała normalizowaniu ich wizerunku. Kilka lat temu powstała dyscyplina fat studies, która przygląda się temu, co ludzie i społeczeństwa sądzą na temat ludzkiej wagi. Do założeń tej dyscypliny należy sceptycyzm względem krzywdzących i wykluczających przekonań związanych $\mathrm{z}$ wagą ${ }^{31}$. Jak wskazuje Cooper, po wielu latach działania ruchu dyskryminacja

22 L. Gerhardt, The Rebellious History of the Fat Acceptance Movement, https://centerfordiscovery.com/blog/fat-acceptance-movement/ (dostęp: 14.05.2021).

${ }^{23}$ Curves Have Their Day in Park; 500 at a 'Fat-in' Call for Obesity, The New York Times Archives, https://www.nytimes.com/1967/06/05/archives/curves-have-their-day-in-park-500-at-afatin-call-for-obesity.html (dostęp: 14.05.2021).

24 Ch. Cooper, op. cit.

25 About Us, National Association to Advance Fat Acceptance (NAAFA), https://naafa.org/ aboutus (dostęp: 14.05.2021).

${ }^{26}$ M. Foreman, The Fat Underground and the Fat Liberation Manifesto 20.12.2018, https:// sites.williams.edu/eng1113-f18/foreman/the-fat-underground-and-the-fat-liberation-manifesto/, (dostęp: 14.05.2021).

27 J. Freespirit, Aldebaran, Fat Liberation Manifesto, „Off Our Backs” 9, 1979, nr 4, www.jstor. org/stable/25773035 (dostęp: 14.05.2021).

28 S. Orbach, Fat Is A Feminist Issue: How to lose weight permanently - without dieting, London 1978.

${ }^{29}$ Ch. Cooper, op. cit. ,popularised ideas that dieting and body hatred are oppressive and that body dysmorphia and eating disorders are rooted in misogyny".

30 Ibidem.

31 J. Lindsay, Fat Studies 4.02.2020, https://newdiscourses.com/tftw-fat-studies/ (dostęp: 14.05.2021). 
osób grubych i otyłych uznana została za mizoginistyczną, seksistowską i podporządkowaną patriarchalnemu społeczeństwu ${ }^{32}$.

\section{Body positivity}

Normalizowanie przez amerykańskich aktywistów i amerykańskie aktywistki tkanki tłuszczowej i życia osób grubych w przestrzeni publicznej stało się zapalnikiem do zabrania głosu w sprawie swoich ciał przez osoby wykluczane ze względu na niedopasowanie do kanonów piękna. Choć za początek body positivity najczęściej uznaje się założenie w 1996 roku przez Connie Sobczak i Elizabeth Scott organizacji The Body Positive ${ }^{33}$, nierzadko historię fat activism traktuje się jako tożsamą z historią powstania ruchu ciałopozytywności, co można zauważyć chociażby w anglojęzycznej wersji owych haseł w Wikipedii ${ }^{34}$. Wydaje się jednak, że choć motywacje obu ruchów w pewnych kwestiach mogą być tożsame, to działania fat-aktywistycznych środowisk na rzecz społecznej zmiany postrzegania ciała stanowiły raczej początek dyskusji o wyglądzie w szerszym rozumieniu. Jak wskazuje Céline Leboeuf, ruch ciałopozytywności opiera się na akceptacji własnego ciała niezależnie od jego płci, koloru skóry, rozmiaru, kształtu i zdolności fizycznych $^{35}$, przez co poszerza przyjęte kulturowo rozumienie standardów piękna ${ }^{36}$.

Connie Sobczak opowiada historię powstania pierwszej ciałopozytywnej organizacji w podkaście „The Growing Woman Podcast”, w odcinku zatytułowanym How I Started The Body Positive ${ }^{37}$. Działania na rzecz samoakceptacji określa jako odroczoną konsekwencję osobistych problemów związanych z zaburzeniami odżywiania. W rozmowie z Christiną Singh Sobczak opisuje własną drogę do zmiany myślenia o swoim ciele. Rozpoczyna od nakreślenia kontekstu amerykańskiej rzeczywistości lat swojej młodości, gdy komentowanie wyglądu kobiecego ciała stanowiło powszechną praktykę. Negatywne opinie ojca na temat wyglądu jej siostry oraz przechodzenie rówieśników na dietę przekładały się na jej rozumienie świata i doprowadziły do tego, że Sobczak w wieku piętnastu lat zachorowała na bulimię. Wspomina: ,wtedy nie było na nią nazwy, wszyscy ją mieli, to było znormalizowane zachowanie wśród mojej grupy znajomych"38. Konsekwencją wieloletniej choroby było pojawienie się w jej życiu myśli samobójczych. W 1981 roku

32 Ch. Cooper, What's Fat...

33 Ch. Singh, How I Started The Body Positive with Connie Sobczak, The Growing Woman Podcast, https:/www.youtube.com/watch?v=9nL1m_0dT7s (dostęp: 8.04.2021).

34 Fat acceptance movement, https:/en.wikipedia.org/wiki/Fat_acceptance_movement oraz Body positivity, https://en.wikipedia.org/wiki/Body_positivity (dostęp: 15.05.2021).

35 C. Leboeuf, What Is Body Positivity? The Path from Shame to Pride, „Philosophical Topics” 47, 2019, nr 2, s. 113.

36 Ibidem, s. 123.

37 Ch. Singh, op. cit.

38 Ibidem. 
Sobczak udała się na terapię do Kim Cherin - feministycznej autorki i psycholożki. Sobczak przyznała, że dopiero wtedy zrozumiała, co działo się z nią w ciągu lat, w jaki sposób kulturowe postrzeganie ciała wpłynęło na jej życie i wciąż wpływa na życie innych ludzi.

Początkowo, w połowie lat dziewięćdziesiątych, działania Sobczak były nastawione na pobudzanie wśród nastolatków zmiany myślenia o własnej cielesności. W tym czasie poznała Elizabeth Scott, terapeutkę, z którą współpracę rozpoczęła od stworzenia grantowego programu leadershipowego dla nastolatków. Obecnie The Body Positive ${ }^{39}$ to organizacja non profit, która zajmuje się edukacją. Na stronie organizacji można przeczytać: ,pomagamy rozwijać zrównoważoną, pozytywną samoopiekę i relację z ciałem, z pomocą miłości, przebaczenia i humoru" ${ }^{\text {"40. }}$ Działania organizacji wspierane są przez liczne programy kierowane do osób prywatnych, edukatorów, studentów oraz dostawców usług medycznych i opierają się na tak zwanym The Be Body Positive Model. To model oparty na rozwoju pięciu podstawowych kompetencji ${ }^{41}$, które mają pomóc w osiągnięciu stanu samoakceptacji i spokoju. Proces ten został opisany w książce Embody: Learning To Love Your Unique Body (and quiet that critical voice!) ${ }^{42}$.

Warto zauważyć także internetową działalność organizacji - na platformie Instagram posiada ona ponad 36 tys. obserwujących, a na Facebooku obserwuje ją ponad 15 tys. użytkowników. Co ciekawe, choć dostępne na stronie internetowej teksty odnoszą się do problematyki postrzegania własnego ciała, nie odnajdziemy na niej bezpośredniej definicji ciałopozytywności. Samo zjawisko opisywane jest jako Body Positive lub The Body Positive Movement, a nie za pomocą rzeczownika bodypositivity.

W dniu 20 maja 2021 roku hashtag \#bodypositive został użyty ponad $15 \mathrm{mln}$ razy, a \#bodypositivity — prawie 7,5 mln razy, polskie tłumaczenie zaś - \#ciałopozytywność - osiągnęło popularność sięgającą 10 tys. użyć. W aplikacji TikTok filmy oznaczone hashtagiem \#bodypositivity obejrzane zostały ponad 10 bilionów razy, a \#ciałopozytywność osiągnął popularność wynoszącą ponad 15 mln odtworzeń. Tym samym wydaje się, że zapoczątkowane przez dwie aktywistki hasło The Body Positive osiągnęło popularność przekraczającą swoje pochodzenie i stało się samostanowiącym nośnikiem znaczeniowym.

39 The Body Positive, thebodypositive.org (dostęp: 14.05.2021).

40 Ibidem, ,we have been helping people develop balanced, joyful self-care and a relationship with their bodies that is guided by love, forgiveness, and humor [przel. - K.W.]".

${ }^{41} \mathrm{Na}$ stronie internetowej organizacji The Body Positive (thebodypositive.org) wskazane są następujące kompetencje: kompetencje przywracania zdrowia, praktyka intuicyjnej samoopieki, pielęgnowanie miłości własnej, deklarowanie własnego, autentycznego piękna i budowanie społeczności.

42 C. Sobczak, Embody: Learning To Love Your Unique Body (and quiet that critical voice!), Carlsbad 2014. 
Na polskim rynku wydawniczym tematyka ciałopozytywności też zaczyna cieszyć się popularnością odzwierciedlającą zainteresowanie widoczne w mediach społecznościowych, w odniesieniu do pozytywnego autowizerunku w kontekście diety, a nawet wychowania. Wśród nich znajdują się zarówno tłumaczenia, na przykład wydana w Polsce w 2019 roku książka Mary Altman Obrzydliwa anatomia $^{43}$, jak i rodzime publikacje o charakterze poradnikowym, w tym:

— autorski e-book wydany w 2019 roku przez polską youtuberkę Red Lipstick Monster Ciałopozytywny poradnik śniadaniowy ${ }^{44}$,

— książka Barbary Pietruszczak o dojrzewaniu dla dziewczynek Twoje pozytywne dojrzewanie: przewodnik po zmianach $w$ ciele, pierwszej miesiaczce $i$ ciatopozytywności $i^{45}$.

Warto dodać, że wydawnictwo moonka przy okazji debiutu książki Pietruszczak wydało grę ,moonka: Dorastanie. Rodzinna, ciałopozytywna gra edukacyjna"46, której celem ma być stworzenie przestrzeni do rozmowy w rodzinie i wspólne spędzanie czasu wolnego.

\section{Body neutrality}

Historia koncepcji ciałoneutralności wciąż nie jest podejmowana w literaturze naukowej, w formatach zaś dziennikarskich jest przedstawiana w sposób niejednoznaczny. W internecie odnaleźć można liczne artykuły podające sprzeczne informacje dotyczące czasu i pobudek powstania tej koncepcji. Określane mianem „,nowej ciałopozytywności” ${ }^{\text {„47 }}$ podejście zakłada rezygnację z konieczności (trudnej do osiągnięcia) samoakceptacji i samo-miłości i daje możliwość przeniesienia uwagi w ocenie siebie i innych ludzi z ciała na wnętrze ${ }^{48}$. Sam termin body neutrality najprawdopodobniej został stworzony w 2010 roku na rzecz programu leczenia w Women's Centre for Binge and Emotional Eating w Vermont w Stanach Zjednoczonych i miał pomóc pacjentkom uwolnić się od nienawiści do samych siebie $^{49}$. Pomimo niewielu rzetelnych informacji dotyczących źródeł powstania i sposobów promocji neutralnego podejścia do ciała, to podejście jest zauważalne medialnie. W portalu Instagram \#bodyneutrality został użyty ponad 146 tys. razy,

43 M. Altman, Obrzydliwa anatomia, przeł. E. Androsiuk, Białystok 2019.

44 E. Grzelakowska-Kostoglu, Ciałopozytywny poradnik śniadaniowy, https://redlipstickmonster.pl/ (dostęp: 13.05.2021).

45 B. Pietruszczak, Twoje ciałopozytywne dojrzewanie: przewodnik po zmianach wciele, pierwszej miesiączce i ciałopozytywności, Warszawa 2021.

$46 \mathrm{https} / /$ moonka.pl/kategoria/sklep/moonka-dorastanie-gra (dostęp: 13.05.2021).

47 M. Park, Concept: Body Neutrality, https://www.onewomanproject.org/blog/2020/9/9/concept-body-neutrality (dostęp: 14.05.2021).

48 P. Reid, Body Positivity is destructive. Body Neutrality is constructive, https://thebrag.com/ body-neutrality/ (dostęp: 14.05.2021).

49 K. Nicholls, What is Body Neutrality?, https://happiful.com/what-is-body-neutrality/ (dostęp: 13.05.2021). 
a jego polski odpowiednik \#ciałoneutralność 539 razy. W aplikacji TikTok filmy oznaczone hasztagiem \#bodyneutrality zostały obejrzane przez 159 mln użytkowników, \#bodyneutral osiągnął wynik $56 \mathrm{mln}$ wyświetleń, a polskojęzyczny \#ciałoneutralność zyskał 12 mln wyświetleń.

\section{Podsumowanie}

Ciałopozytywność i ciałoneutralność to medialnie atrakcyjne zjawiska społeczne, które zaistniały w polskiej rzeczywistości za sprawą rosnącej popularności w mediach społecznościowych. Stojące za tymi pojęciami sposoby rozumienia ciała i cielesności trafiają na niemający długiej historii ruchu fat activism polski grunt i zyskują nowe znaczenia, które w dużym stopniu nie są lustrzanym odbiciem anglojęzycznych odpowiedników. Wydaje się, że nowe sposoby rozumienia cielesności, stanowiące swego rodzaju odzwierciedlenie nastrojów i wartości społecznych, będą rosły w siłę, dlatego ich definicje, konteksty użycia czy współistniejące z nimi zjawiska są obszarami, które powinny zostać objęte szerszą refleksją badawczą również w Polsce. Warto zwrócić uwagę, że to właśnie ciałopozytywność i ciałoneutralność zmieniają postawiony przez fatactivistów warunek normalizacji i akceptacji przez społeczeństwo ciał osób niewpisujących się w kanony piękna na rzecz wizerunku własnego. Wydaje się więc, że zmiana tej perspektywy możliwa jest dzięki wieloletniej działalności organizacji i ruchów na rzecz fat activismu, które wskazały na taką możliwość i wspierały akceptację niekanonicznych ciał jednostek.

\section{Bibliografia}

About Us, National Association to Advance Fat Acceptance (NAAFA), https://naafa.org/aboutus.

Altman M., Obrzydliwa anatomia, przeł. E. Androsiuk, Białystok 2019.

The Body Positive, thebodypositive.org.

Body positivity, https://en.wikipedia.org/wiki/Body_positivity.

Ciałopozytywność, https://sjp.pl cia\%C5\%82opozytywno\%C5\%9B\%C4\%87.

Ciałopozytywność - czy rzeczywiście zawsze tak pozytywna jak nam się wydaje, 22.11.2020, https://www.tamaragonzalezperea.com/2020/11/cialopozytywnosc-czy-rzeczywiscie-zawsze-tak-pozytywna-jak-nam-sie-wydaje.html.

Cooper Ch., Fat Activism: A Queer Autoethnography, 2020, https://core.ac.uk/download/ pdf/59349191.pdf.

Cooper Ch., What's Fat Activism?, 2008, https:/ulir.ul.ie/bitstream/handle/10344/3628/Cooper_2008_fat.pdf.

Curves Have Their Day in Park; 500 at a 'Fat-in' Call for Obesity, „The New York Times” Archives, https://www.nytimes.com/1967/06/05/archives/curves-have-their-day-in-park-500-at-afatin-call-for-obesity.html.

Dąbrowska D., Filmowe przedstawienie otyłości - od krytyki do emancypacji, „Annales Universitatis Paedagogicae Cracoviensis. Studia de Cultura" 12, 2020, nr 4.

Dec T., Ciałopozytywność, Obserwatorium Językowe Uniwersytetu Warszawskiego Najnowsze Słownictwo Polskie, https://nowewyrazy.pl/haslo/cialopozytywnosc.html. 
Fat acceptance movement, https://en.wikipedia.org/wiki/Fat_acceptance_movement.

Foreman M., The Fat Underground and the Fat Liberation Manifesto, 20.12 .2018 , https://sites.williams.edu/eng1113-f18/foreman/the-fat-underground-and-the-fat-liberation-manifesto/.

Freespirit J, Aldebaran, Fat Liberation Manifesto, „Off Our Backs” 1979, t. 9, nr 4, www.jstor.org/ stable/25773035.

Gerhardt L., The Rebellious History of the Fat Acceptance Movement, https://centerfordiscovery. $\mathrm{com} / \mathrm{blog} /$ fat-acceptance-movement/.

Grzelakowska-Kostoglu E., Ciałopozytywny poradnik śniadaniowy, https://redlipstickmonster.pl.

https://moonka.pl/kategoria/sklep/moonka-dorastanie-gra.

https://nowewyrazy.pl/haslo/cialopozytywnosc.html.

https://pl.pons.com/t\%C5\%82umaczenie/angielski-polski/fat.

Leboeuf C., What Is Body Positivity? The Path from Shame to Pride, „Philosophical Topics” 47, 2019, nr 2., s. 113-128.

Lindsay J., Fat Studies, 4.02.2020, https://newdiscourses.com/tftw-fat-studies/.

Mróz A., Inność a Tożsamość: Estetyka mężczyzn w obliczu toksycznej męskości, „Kultura i Historia” 35,2019 , nr 1, s. 75-90.

Nicholls K., What is Body Neutrality?, 4.02.2019, https://happiful.com/what-is-body-neutrality/.

Orbach S., Fat Is A Feminist Issue: How to lose weight permanently - without dieting, London 1978.

Park M., Concept: Body Neutrality, 14.10.2020, https://www.onewomanproject.org/blog/2020/9/9/ concept-body-neutrality.

Pietruszczak B., Twoje ciałowpozytywne dojrzewanie: przewodnik po zmianach w ciele, pierwszej miesiączce i ciałopozytywności, Warszawa 2021.

Reid P., Body Positivity is destructive. Body Neutrality is constructive, 5.07.2019, https://thebrag. com/body-neutrality/.

Seiler K., Juz nie body positiv, tylko body neutrality. Nowy feministyczny ruch walczy z kultem ciała, 20.11.2019, https://www.wysokieobcasy.pl/wysokie-obcasy/7,80530,25423882,juz-nie-body-po sitive-tylko-body-neutrality-nowy-feministyczny.html?disableRedirects=true.

Singh Ch., How I Started The Body Positive with Connie Sobczak, The Growing Woman Podcast, 29.07.2020, https://www.youtube.com/watch?v=9nL1m_0dT7s.

Szulczewska K., @kayashu https://www.instagram.com/kayaszu/?hl=pl.

Woźniak A., Pomęczę ciało, żeby ulżyć duszy. Jak nauczyć się akceptować siebie i swoją cielesność, 23.10.2020, https://www.wysokieobcasy.pl/Instytut/7,163393,26426309,pomecze-cialo-zeby-ulzyc-duszy-jak-nauczyc-sie-sie-akceptowac.html. 